\title{
Entre um sistema eleitoral dispersivo e um regramento parlamentar concentrador - O comportamento dos deputados federais da 53a Legislatura
}

\author{
Júlio Roberto de Souza Pinto \\ Orientador: Prof. Dr. Caetano Ernesto Pereira de Araújo \\ Curso: Doutorado de Sociologia \\ Data da Defesa: 9.07.2010
}

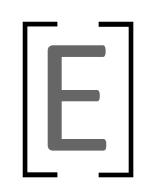

ste trabalho - empregando uma metodologia construída sobre formulações feitas por Jürgen Habermas, Pierre Bourdieu e Anthony Giddens - procura combinar uma explicação da ação dos deputados federais da 53a Legislatura (2007-2011), a partir de elementos estruturais, sobretudo as constrições e as potencialidades objetivas inscritas nas estruturas partidárias, com uma compreensão das representações que esses parlamentares fazem da própria conduta. No curso desse processo, busca explicar/compreender a influência da combinação presidencialismo/representação proporcional com lista aberta, de um lado, e da combinação de poder de agenda do presidente da República/centralização dos trabalhos da Câmara dos Deputados nas mãos dos líderes partidários, de outro, sobre o comportamento parlamentar, assim como as ações dos deputados tendentes a reproduzir ou transformar esse estado de coisas. Conclui que as regras políticas vigentes no Brasil, juntamente com outros fatores, notadamente culturais, têm concorrido para a formação de uma multiplicidade de partidos políticos fracos, com pouca capilaridade social, identidade ideológico-programática e coesão, consistindo de políticos individualistas, particularistas, personalistas e apartidários, bem como de lideranças parlamentares que não conseguem influenciar, de modo decisivo, o comportamento das respectivas bancadas. Em compensação, o governo tem ocupado todos os vazios de poder que os partidos e as lideranças partidárias não têm sido capazes de preencher nas estruturas da Câmara dos Deputados. Valendo-se dos poderosos recursos postos a sua disposição, o governo tem definido a configuração do tabuleiro político da Câmara, não somente cooptando deputados da oposição, mas também determinando a escolha e a manutenção dos líderes das bancadas partidárias que integram sua base de susten- 
tação. A análise comparada das últimas tentativas de reforma do sistema eleitoral-partidário, de uma banda, e de limitação dos poderes de agenda do presidente, de outra, deixa claro que o governo é a grande força mobilizadora das estruturas existentes na Câmara dos Deputados.

Palavras-chave: ação parlamentar; estrutura partidária; sistema eleitoral dispersivo; regramento parlamentar concentrador; reforma política; limitação dos poderes legislativos do presidente da República. 